\title{
Diabetes and Insurance
}

\author{
Sujoy Ghosh ${ }^{1}$ Pradip Mukhopadhyay ${ }^{1} \quad$ Sarita Bajaj² \\ 1Department of Endocrinology and Metabolism, I.P.G.M.E\&R, West \\ Bengal, India \\ 2Department of Medicine, Motilal Nehru Medical College, Prayagraj, \\ Uttar Pradesh, India \\ Address for correspondence Sarita Bajaj, MD, DM, FRCP, \\ Department of Medicine, Regional Institute of Medical Sciences, \\ Lamphel Road, Lamphelpat, Imphal, Manipur 795004, India \\ (e-mail: drsarita.bajaj@gmail.com).
}

\begin{abstract}
Keywords

- healthcare expenditure

- financial burden

- term versus life insurance

- healthcare education

India has healthcare expenditure of more than 5 billion dollars on diabetes-related healthcare management. Globally, approximately $12 \%$ of health expenditure is spent on diabetes and related comorbidities. Hospitalization includes hospital and laboratory expenses and cost of medications as the direct cost. India is among the countries, where if the insured dies during the time period specified in the insurance policy and the policy is active, or in force, then a death benefit will be paid. Studies in India reported that medical reimbursement is availed by $21.3 \%$ in the high-income group and only $6.4 \%$ of the urban low-income group. An average cost of management of diabetic complications like diabetic foot, retinopathy, and patients with two complications was almost close to the average cost of claimed amount. Patients may be advised to take insurance for diabetes when there is any indication of future disease and risk factors contributing to diabetes like a strong family history, obesity, hypertension, and other vascular diseases. Diabetes Safe from Star Health and Varistha Mediclaim from National Insurance were among the first insurance policies to be launched in India.
\end{abstract}

\section{Introduction}

Active management of Type 2 diabetes is a major financial burden to the global economy. Defined as a state of hyperglycemia above certain evidence-based cut offs, it is distressing for several chronic and acute complications which ultimately end up in premature mortality or major irreversible morbidities. Major chronic diabetic complications like diabetic nephropathy, neuropathy, retinopathy, and several macrovascular problems, especially coronary artery diseases (CADs) develop down the years, even when a proactive and guideline-based management approach is adopted for control of glycemia and other risk factors. As per IDF diabetes Atlas 2017, the IDF South-East Asia and Western Pacific regions are at the epicenter of the diabetes crisis: China alone has 121 million people with diabetes and India's diabetes population totals 74 million and is projected to reach 151 million by 2045 . About $12 \%$ of health expenditure is spent on diabetes and related comorbidities globally. India is among the countries which spends more than 5 billion dollars of healthcare expenditure on diabetes-related healthcare management. ${ }^{1}$ Thus, diabetes is one of the biggest health burdens in the world and is increasing progressively over time. Total deaths due to diabetes were around 5 million in 2015. A higher population is from urban areas (269.7 million) when compared with the rural (145.1 million).

Despite India's large diabetes population, it is unfortunate that a negligible number of insurers come forward to specifically address the needs of persons living with diabetes with regard to the all-round insurance requirements. Insurance companies are primarily interested in providing term insurance to such people. Term insurance is a type of life insurance policy that provides coverage for a certain period of time or a specified "term" of years. If the insured dies during the time period specified in the policy and the policy is active, or in force, then a death benefit will be paid. Term insurance is initially much less expensive when compared with permanent life insurance. Unlike most types of permanent insurance, term insurance has no cash value.

However, when it comes to comprehensive health insurance, rarely if any, companies are willing to provide such coverage for diabetes and its complications for persons living with this chronic disease.

The plausible explanation may be that although diabetes is associated with various complications, the probability is fairly good that the insured will survive the policy term. Therefore, the costs the person incurs for the treatment of 
the disease and its complication are likely to be high and hence the insurers are reluctant to provide these patients with comprehensive coverage that tackles such costs.

\section{Financial Burden and Diabetes-Related Healthcare Cost}

Increasing prevalence of diabetes is the major risk factor for the exponentially increasing prevalence of macro and microvascular complications which ultimately results in increased morbidity and mortality among patients with long-standing disease. However, studies regarding the economic burden of diabetes in India are scarce. Foot problems, which are directly or indirectly related to various diabetic complications, remain one of the major chronic morbidities and require more frequent hospitalisation. ${ }^{2}$ However a study by Kumpatla et al stated that retinopathy was the major cause of hospitalization followed by diabetic foot that includes amputation and management of existing symptoms related to the diabetic foot. The mean number of hospitalized days for diabetic foot and retinopathy complications was 6 and 5 days respectively, and patient hospitalized with two complications also spent 6 days on an average. Estimates as of 2013 reveal that on an average, patients with foot complications (19020 INR) and those who had two complications (17633 INR) spent four times more and patients with renal disease (12690 INR), cardiovascular (13135 INR), and retinal complications (13922 INR) spent three times more than patients without any complications (4493 INR).

Spending such an amount to manage diabetic complications during the hospital stay is a major financial burden for patients with diabetes and is increasing by many folds due to inflation and other indirect burdens to the patients caused by loss of working hours apart from other functional abilities.

India as a developing country is facing a huge economic burden in the area of management of diabetes and its complications, which affects the quality of care in different population groups. It is noteworthy that patients from the rural area and the middle-income group are particularly facing a tremendous challenge. Delay in diagnosis and treatment of early symptoms contributes to increased prevalence of complications, while hospitalization or severe illness due to diabetes warrants an expenditure of the large portion of income to manage. It includes hospital expense, laboratory expense, and cost of medications as the direct cost. ${ }^{3}$ It was postulated that the total annual cost of diabetes care in India was INR 1230 to 1837.3 billion in $2010 .^{4}$

\section{Diabetes and Insurance: Indian Scenario}

The absence or lack of social security system or any health insurance to patients in India requires support from family, and if the prime member of the family suffers from any chronic illness, the entire family suffers. Tharkar et al reported that more than $60 \%$ of patients from the low-income group had to lend or mortgage property for the treatment of diabetes and its complications while the high-income group patients, approximately 70 to $80 \%$, spent a large portion of their savings on the treatment. Health insurance for reimbursement of medical expenses is not being used efficiently in developing countries like India. In a study by Smith-Spangler et al, health insurance had a very unsatisfying role in reducing medical expenditure. ${ }^{5}$ Ramachandran et al reported that only $6.4 \%$ of the low-income group and $21.3 \%$ of the high-income group had received medical reimbursement, reflecting that only high-income group utilized health insurance to some extent and had a better understanding of Mediclaim policies. ${ }^{2}$

A study by Yesudian et $\mathrm{l}^{6}$ reported that urban group had the highest economic burden due to their lifestyle modification as compared with the rural group, which had increased physical activity that delays the disease and its complications. It was stated that private sector manages the biggest corner of financial and delivery of healthcare in India. In the year 2012, healthcare budget was lower in India than other countries in the region, that is, $33 \%$ of total healthcare expenditure when compared with $52 \%$ in other SouthEast Asian countries. According to a report by World Bank in 2012, central and state government was responsible for insuring only $19 \%$ of the population ( 240 million people) in 2010. Along with private insurance and other schemes, it increases to $25 \%$ of the population (300 million people).

Despite the above-mentioned data, the majority of developing nations still do not put the concept of medical reimbursement in the form of insurance policies into its full use. In an analysis using data from 35 low- and middle-income countries, such as Kenya, Vietnam, Bangladesh, Mali, Ethiopia, Pakistan and India, included in the World Health Survey, Smith-Spangler et al reported that health insurance had a meagre role in reducing the medical expenses of diabetic individuals. ${ }^{8}$ Studies in India reported that only $6.4 \%$ of the urban low-income group received medical reimbursement, whereas this was $21.3 \%$ in the high-income group. ${ }^{2}$ This implies that, even in urban settings, the concepts of health insurance and Mediclaim policies are better understood and utilized by the high-income group. Health resources in India and other developing countries are very limited with only 5\% of gross domestic product (GDP) being spent on healthcare. ${ }^{9}$ The majority of healthcare expenditure was private ( $4 \%$ of GDP) with only $0.9 \%$ of GDP spent on public healthcare. Therefore, careful planning based on health economic assessments is necessary to maximize the use of funds for the treatment and prevention of diabetes. ${ }^{9}$

\section{Claims Related to Diabetes Health Insurance}

A report published in the Economic Times in November 2016 stated that diabetes may not be as dangerous as cardiac or cancer disease, but the treatment of diabetes and its complication is much more expensive. The average monthly expense for the treatment of diabetes was estimated between INR 5,000 to 9,000 and that includes only consultation and diagnostic cost. The additional complication may raise the expense up to INR 20,000 per month. Since diabetes is a never-ending disease, it requires a higher amount of insurance claim, as high as 
$90 \%$, when compared with other diseases. In the report, it was summarized that total claims reported in the financial year 2015-16 were two times higher than the previous year, with more than $50 \%$ of claims reported by people aged between 41 to 60 years. Twenty four percent claims were made for surgical treatments, while $76 \%$ were made for only conservative treatment. Maharashtra and Kerala were top cities to make claims among the top 10 cities in India (Maharashtra, Kerala, Tamil Nadu, Gujarat, Karnataka, West Bengal, Andhra Pradesh, Uttar Pradesh, Delhi, and Madhya Pradesh). ${ }^{9}$

According to a report published in the Economic Times in April 2016, the average claim size for a diabetic policyholder was estimated at INR 50,000 and is rising by $18 \%$ every year. ${ }^{10}$ As mentioned above, the average cost of management of diabetes complications like diabetic foot, retinopathy, and patient with two complications was INR 7,200 to $67,300,{ }^{11}$ which is almost close to the average cost of claimed amount. It can be said that making diabetes health insurance can decrease a huge economic burden on the policy holder and his or her family, which can boost the financial and social status of the individual.

\section{Benefits and Recommendation While Choosing Diabetes Insurance}

For a healthy individual, having a health cover plan like a Mediclaim, with adequate sum insured, could be adequate to meet the hospitalization costs arising out of a diabetic situation; however, in such a case, future renewals and coverage may get altered. Therefore, on detection of diabetes, a diabetes specific insurance plan helps. Thus, a person may be advised to take diabetic insurance when there is any indication for the future disease and risk factors for diabetes like a strong family history, obesity, hypertension, and other vascular diseases are present. As mentioned above, treating diabetes and its complications requires a lot of financial expenditure largely at the time of hospitalization which is almost directly proportional to the severity of the disease. The benefit of buying a diabetic health insurance is that it covers the treatment of diabetes along with its complications, which may boost the confidence of a patient to keep on the target.

The health insurance sector in India is not much popular in rural areas and this affects, to a great extent, the fulfillment of healthcare needs. Patients must be advised to buy insurance plan early enough to get enough control over disease and financial stress. Buying an insurance to cover diabetes may cost around 2.5 times higher amount in a year when compared with general health insurance for a healthy person. It would be good enough if a person also considers additional benefits in their policy for outpatient department (OPD) claims along with extra protection for their family with additional premium. ${ }^{12}$

\section{Health Insurer's Offering Plan For Diabetics in India}

Currently, available health covers that include diabetes and related complications do not provide it before a 4-year

Table 1 Available health insurance plans for diabetic patients in India

\begin{tabular}{|c|c|c|c|c|c|c|}
\hline SI. No. & Health Plan & Eligibility & $\begin{array}{l}\text { Entry-exit } \\
\text { Age }\end{array}$ & $\begin{array}{l}\text { Sum Insured } \\
\text { (in ₹ ) }\end{array}$ & $\begin{array}{l}\text { Premium Starts from } \\
\text { (₹) }\end{array}$ & Coverage \\
\hline 1 & $\begin{array}{l}\text { Star Health } \\
\text { Diabetes Safe }\end{array}$ & $\begin{array}{l}\text { Any person who } \\
\text { is diagnosed } \\
\text { with Diabetes } \\
\text { Mellitus Type } \\
1 \text { or } 2\end{array}$ & $\begin{array}{l}\text { 18-65 years } \\
\text { (Renewals } \\
\text { can be made } \\
\text { lifelong) }\end{array}$ & $\begin{array}{l}\text { INR 3,00,000- } \\
10,00,000\end{array}$ & INR 6825 per year & $\begin{array}{l}\text { Complications of diabetes } \\
\text { (both Type } 1 \text { and Type } 2 \text { ), } \\
\text { regular hospitalization, } \\
\text { personal accident, and } \\
\text { outpatient expenses }\end{array}$ \\
\hline 2 & $\begin{array}{l}\text { National Insur- } \\
\text { ance Varistha } \\
\text { Mediclaim }\end{array}$ & $\begin{array}{l}\text { Any person } \\
\text { aged between } \\
60 \text { to } 80 \text { years }\end{array}$ & $\begin{array}{l}60-80 \text { years } \\
\text { (renewal up to } \\
90 \text { years) }\end{array}$ & $\begin{array}{l}1,00,000 \text { (plain } \\
\text { cover) } \\
\text { or } \\
2,00,000 \text { (with } \\
\text { critical illness } \\
\text { cover added) }\end{array}$ & INR 4180 & $\begin{array}{l}\text { Coronary artery surgery, } \\
\text { renal failure, stroke, Kidney } \\
\text { transplants paralysis and } \\
\text { blindness at extra premium, } \\
\text { pre-existing hypertension, } \\
\text { and/or diabetes is covered } \\
\text { with additional premium } \\
@ 10 \% \text { for either hypertension } \\
\text { or diabetes \& } 20 \% \text { for both }\end{array}$ \\
\hline $\begin{array}{l}\text { SL. } \\
\text { No. }\end{array}$ & Health Plan & Eligibility & $\begin{array}{l}\text { Entry-exit } \\
\text { Age }\end{array}$ & $\begin{array}{l}\text { Base Sum } \\
\text { Assured }\end{array}$ & Premium Starts from (₹) & Coverage \\
\hline 1 & $\begin{array}{l}\text { ICICI Prudential } \\
\text { Diabetes Care }\end{array}$ & $\begin{array}{l}\text { Type } 2 \text { Diabetics } \\
\text { or Prediabetics }\end{array}$ & $\begin{array}{l}25-60 \text { years } \\
\text { Long-term } \\
\text { coverage up to } \\
65 \text { years of age }\end{array}$ & $\begin{array}{l}\text { Options of } \\
3 \text { lakh, } 5 \text { lakh, } \\
\text { and } 10 \text { lakhs }\end{array}$ & $\begin{array}{l}\text { INR } 7236-15385 \text {, for a } \\
\text { policy of } 3 \text { lakhs }\end{array}$ & $\begin{array}{l}\text { PTCA,CABG, AMI, Stroke } \\
\text { Cancer, End Stage renal Fail- } \\
\text { ure, Major organ transplant } \\
\text { (as recipient) }\end{array}$ \\
\hline 2 & $\begin{array}{l}\text { Apollo Munich } \\
\text { Energy Health } \\
\text { Insurance Plan } \\
\text { Gold: includes } \\
\text { wellness test cost. } \\
\text { Silver excludes } \\
\text { the cost }^{a}\end{array}$ & $\begin{array}{l}\text { Type } 1 \text { or } 2 \\
\text { Diabetes or } \\
\text { Pre-Diabetes }\end{array}$ & $\begin{array}{l}\text { 18-65 years } \\
\text { (No age limit } \\
\text { on renewa- } \\
\text { bility) }\end{array}$ & $\begin{array}{l}\text { Ranges from } \\
2 \text { lakhs to } \\
50 \text { lakhs }\end{array}$ & $\begin{array}{l}\text { INR } 12306 \text { for Silver Plan } \\
\text { and INR } 17306 \text { for Gold } \\
\text { Plan (for sum insured of } \\
5 \text { Lakh) for person aged } \\
36-45 \text { years: increas- } \\
\text { es with age and sum } \\
\text { insured }\end{array}$ & $\begin{array}{l}\text { Coverage for all hospitaliza- } \\
\text { tion resulting from Diabetes } \\
\text { and Hypertension (pre and } \\
\text { post hospital coverage of } 30 \\
\text { and } 60 \text { days respectively) }\end{array}$ \\
\hline
\end{tabular}

aNewer players in this rarefied market include ICICI Prudential and Apollo Munich Health. ICICI Prudential currently offers a long term plan named Diabetes Care Active for those diagnosed with Type 2 Diabetes and Pre-Diabetics (IFG/IGT). Apollo Munich offers its Energy Health Insurance Plan with Gold and Silver variants. 
waiting period postdiagnosis. Certain policies that do provide diabetes coverage earlier than 4 years have very high premium. In case of most health plans, diabetes and hypertension always features as an exclusion that are not included after 1,2 , or even 4 years.

So, what does a person with diabetes do in such a situation? A slow and steady approach to get covered is to buy a health plan and wait it through. One should be on the lookout for plans that offer coverage for diabetes and its complications after a shorter-than-usual waiting period. Another way is to get covered by a group health insurance provided by the employer. Such a plan covers against preexisting conditions, including diabetes, but it is active only as long as you are an employee with the organization. Options are limited for patients who are in search of diabetes-related insurance coverage. The following plans, Diabetes Safe from Star Health and Varistha Mediclaim from National Insurance, were among the first of to be launched in India.

Newer players in this rarefied market include ICICI Prudential and Apollo Munich Health. ICICI Prudential currently offers a five-year term plan named Diabetes Care for those diagnosed with Type 2 Diabetes and Pre-Diabetics (IFG/IGT). Apollo Munich offers its Energy Health Insurance Plan with Gold and Silver variants (-Table 1).

\section{Conclusion}

It was seen that major claims related to diabetes insurance come from metro cities in India. The reason is a lack of healthcare education in rural areas, which leads to unawareness about the disease and its management. Most of the patients depend upon their treating physicians, and since the doctor-patient ratio is quite low in India, it is not possible to educate every person by healthcare professionals. In this context, government agencies along with private sector should come up with a proper plan to educate people about different lifestyle and noncommunicable diseases; in terms of diabetes, there should be proper education on diabetes management and how to treat its complications.

\section{Conflict of Interest}

None declared.

\section{References}

1 Executive summary. In: IDF Diabetes Atlas. 7th ed. 2015

2 Ramachandran A, Ramachandran S, Snehalatha C, et al. Increasing expenditure on health care incurred by diabetic subjects in a developing country: a study from India. Diabetes Care 2007;30(2):252-256

3 Viswanathan V, Rao VN. Problems associated with diabetes care in India. Diabetes Manage 2013;3(1):31-40

4 Tharkar S, Devarajan A, Kumpatla S, Viswanathan V. The socioeconomics of diabetes from a developing country: a population based cost of illness study. Diabetes Res Clin Pract 2010;89(3):334-340

5 Smith-Spangler CM, Bhattacharya J, Goldhaber-Fiebert JD. Diabetes, its treatment, and catastrophic medical spending in 35 developing countries. Diabetes Care 2012;35(2):319-326

6 Yesudian CAK, Grepstad M, Visintin E, Ferrario A. The economic burden of diabetes in India: a review of the literature. Global Health 2014;10(80):80

7 La Forgia G, Nagpal S, Government-Sponsored Health Insurance in India: Are You Covered? Directions in Development. Washington, DC: World Bank. 2012

8 WHO. World Health Survey: current status of the World Health Survey. Available at: www.who.int/healthinfo/survey/ en/index. html. Accessed March 30, 2017

9 Kapur A. Economic analysis of diabetes care. Indian J Med Res 2007;125(3):473-482

10 Makers T. In Partnership with Economictimes.com [Internet]. Bengaluru: Why you should get diabetes insurance before it is too late. Available at: http://economictimes.indiatimes.com/ wealth/insure/why-you-should-get-diabetes-insurance-beforeit-is-too-late/articleshow/55451789.cms. Accessed November 21,2019

11 Kumpatla S, Kothandan H, Tharkar S, Viswanathan V. The costs of treating long-term diabetic complications in a developing country: a study from India. J Assoc Physicians India 2013;61(2):102-109

12 The Economic Times. Insure [Internet]. ET Bureau. Why you may need diabetes insurance. Available at: http: //economictimes.indiatimes.com/wealth/insure/why-youmay-need-diabetes-insurance/articleshow/51753474.cms. Accessed March 26, 2017 